\title{
Risk Analysis in the Mining Industry
}

\author{
Undram Chinbat \\ School of Economic Studies, National University of Mongolia \\ Mongolia
}

\section{Introduction}

People in different societies and different economic, political environments perceive and evaluate risks of large and complex projects in significantly distinctive ways. This chapter demonstrates ways of identifying and analyzing risks in large projects using case studies of mining projects in Mongolia.

According to the Project Management Body of Knowledge (PMBOK), composed by the Project Management Institute (PMI), the largest professional organization dedicated to the project management (PM) field, risk management (RM) has been designated as one of the nine main areas (the other eight being integration, scope, time, cost, quality, human resources, communications, and procurement management). Consequently, RM is considered as an important activity of the PM process. The need to identify a project's uncertainties, estimate their impact, analyze their interactions and control them within a risk-management structure has only in recent years been realized, mainly within the defense, construction and oil industries (Williams, 1995).

The chapter explaines risk management processes through a research on mining project risks. For clarity, the chapter will start from explaining about mining projects, providing a simple process flow chart. The next step was to identify risks based on this flow chart and seen in the mining projects implemented in Mongolia. The long-list of the risks may occur during mining project implementation was completed through literature review and discussion with mining engineers and project managers with experience working in Mongolia. Construction project risk and oil and petroleum project risk studies were widely used. The list of identified risks was short-listed by the criteria, which has the most impact to mining project failure during an implementation process in the country. The short-listed risks were assessed and prioritized based on a questionnaire response from the expertise working in the Mongolian mining industry. Finally, a study on project risk information database, methods to create and use the database were formulated.

\section{Project risk}

All projects carry certain level of risk and how this is dealt with affects project success (Gardiner, 2005). Project risk is, defined by the PMI:

Project risk is an uncertain event or condition that, if it occurs, has positive or negative effects on at least one project objective, such as time, cost, scope or quality (Project Management Institute [PMI], 2008). 
Risks can have either positive or negative effect on projects. A recent survey of IT managers reflecting on the idea that risk can have a positive effect revealed that although 49 percent of respondents regarded risk as a negative event, 22 percent of respondents held the view that risk can include positive consequences of some event as well as negative aspects (Charette, 2002). Therefore, all risks cannot be considered as negative. According to Gardiner (2005), there are essentially two categories of risk:

- Speculative risk: meaning a chance of a loss or chance of a profit. For example, an established business could expand and make more profit or it could go bankrupt, so buying stock in this company is a speculative risk. Most projects carry speculative risk.

- Pure risk: meaning only a chance of a loss. For example, jumping out of a moving car involves only the chance of an accident. Pure risks are insurable.

The classification of risks creates a common framework for grouping risks, although different cultures could classify the same risk differently (Wyk et al., 2008). Edwards and Bowen (2005) suggests two primary categories for classifying risks:

- Natural risk: those from systems "beyond human agency" which include risks from weather, geological, biological and extraterrestrial systems.

- Human risk: risks from social, political, cultural, health, legal, economic, financial, technical and managerial systems.

In this chapter all the risks considered as pure risks, and will be written in the text using a term "risk". Furthermore, propositions for managing several human risk were suggested in the chapter.

\subsection{Project risk management}

The need for project risk management (PRM) has been widely recognized. This is particularly so in the case of 'major projects' (Williams, 1995). Fraser (1984) says that 'Normal' projects have the characteristics (amongst others) that "risk assessment can follow well established procedures as all risks are visible", "there are no catastrophic risks", "the scale of individual risks is small compared with the size of the parties involved and therefore there is no completion problem", but that "none of these characteristics is true of the largest projects"; "in general, beyond a certain size, the risks of projects increase exponentially and this can either be appreciated at the beginning or discovered at the end".

Risk management (RM) provides a structured way of assessing and dealing with future uncertainty (Cooper et. al., 2005). PRM is applied in all project phases to identify significant risks and develop measures to address them and their consequences. Once the project starts, RM needs to be an on-going process (Ward \& Chapman, 1991). Implementing a RM process earlier in the project life cycle is useful if it is done effectively (Chapman, 1997). PRM includes the following set of processes (Figure 1):

- Risk identification - process of determining risks that may affect the project;

- Risk analysis - process of assessing risks' probability of occurence and impact on project sucess;

- $\quad$ Risk evalutaion - process of prioritizing risks based on the probability of occurence and impact on project sucess;

- $\quad$ Risk mitigation - process of developing actions to reduce the occurance and/or impact of the negative risks.

- $\quad$ Risk monitoring - process of implementing risk mitigation plans, tracking identified risks, monitoring residual risks, identifying new risks, and evaluating overall risk management process effectiveness throughout the project. 
- $\quad$ Risk learning - process of documenting lessons learned from the PRM activities.

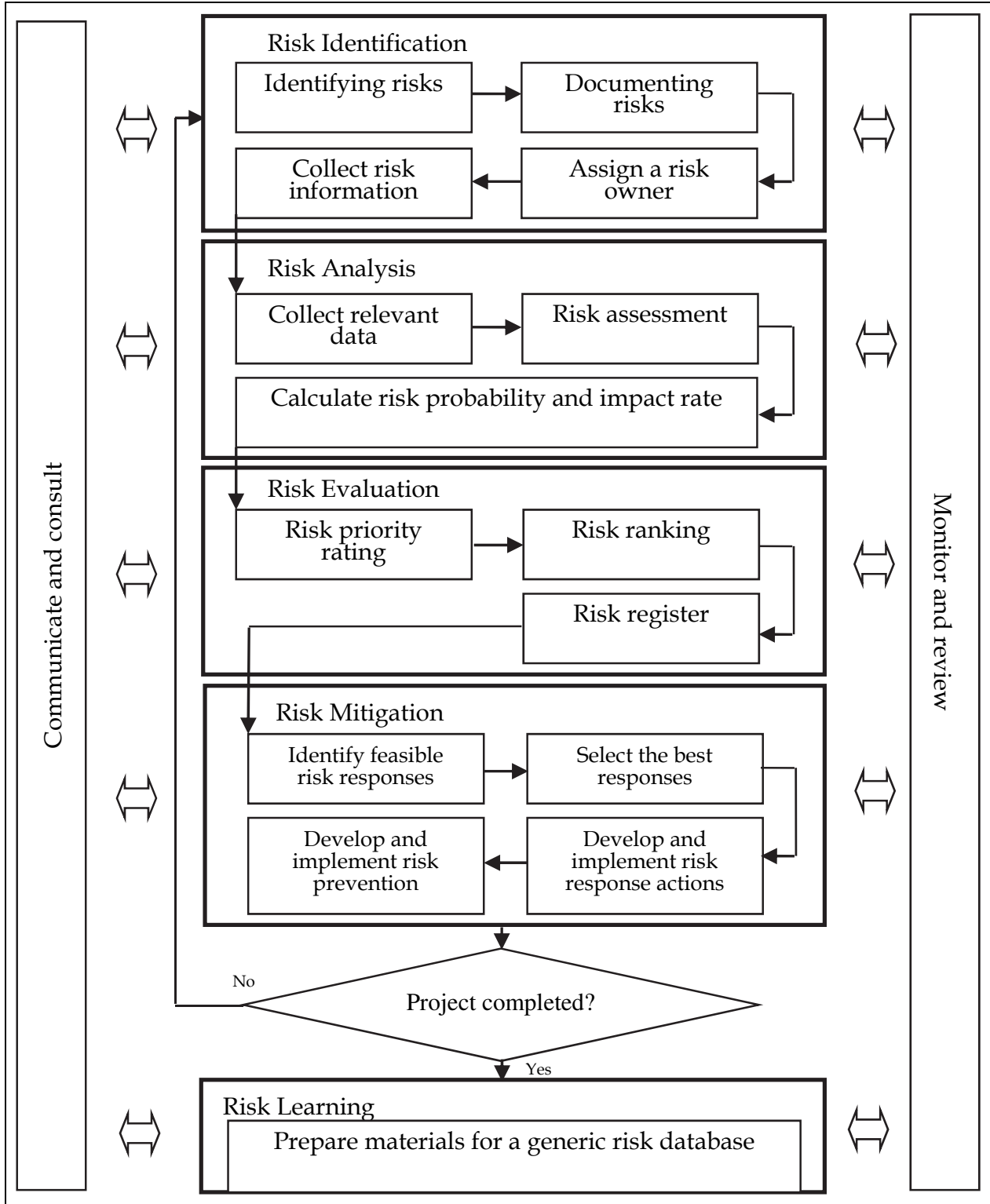

Fig. 1. Risk management process model

The objective of PRM is to reduce the probability and impact of negative risks of a project. The RM is an iterative process throughout the project's life, because new risks may evolve or become known as the project progresses. 


\section{Project risk management in the mining industry}

Up to date, mining industry has not performed well in its ability to deliver projects according to the financial and physical parameters forecast in the feasibility study process. For example, the pace and scale of current developments in Australia's mineral resources sector is worldwide known as unprecedented. A study of eighteen mining projects covering period of 1965 to 1981 showed an average cost overrun of 33 percent compared to their feasibility study estimates (Castle, 1985). A study of sixty mining projects covering the period from 1980 to 2001 showed average cost overruns of 22 percent with almost half of the projects reporting overruns of more than 20 percent (Gypton, 2002). A review of sixteen mining projects carried out in the 1990s showed an average cost overrun of 25 percent, attributed to overly optimistic feasibility studies and poor cost estimation (Anon, 2000, as sited in Noort \& Adams, 2006). Therefore, a standard approach to mining project management, effective tools that can be utilized to meet the project objectives, and studies regarding risk factors associated with mining projects, are required to develop the current project management status of the mining industry.

Mining project activity is subject to high risks because of its size, uncertainty, complexity, and high costs. Large engineering projects are high-stakes games characterized by substantial irreversible commitments, skewed reward structures in case of success, and high probabilities of failure (Miller \& Lessard, 2001). Floricel and Miller (2000) suggested that large scale projects such as power plants, highways, bridges, tunnels, and airports developed in the last 20 years have become increasingly characterized by turbulence resulting from radical shifts in institutional frameworks, political and economic discontinuities, environmental and social activism and, to a lesser extent, technological changes and innovations. Risks caused by these turbulences ought to be considered by project managers for a successful project implementation. The extent of risk and uncertainty associated with construction projects, particularly in remote locations is considerable and should not be underestimated (Perry, 1986). Mining projects are commonly implemented in distant locations, which explicate its need for careful RM. RM becomes an integral part of PM and plays such an important role that its application goes beyond the traditional scope which normally center on the construction phase (del Cano \& de la Cruz, 2002). In the development of an oil field enormous number of issues involved and a lot of risks are associated to them. The limited knowledge about the characteristics of the geological formation, technical facilities, and human behavior results in considerable uncertainty about the oil and gas wells drilling operations (Jacinto, 2002).

A review of the extant literature shows that excluding the numerous studies on construction PRM in various countries, very few studies have been conducted specifically on mining PRs. Several risk analysis studies has been carried on oil field, petroleum exploration. However, only number of studies relevant to PRM based on the geographical uniqueness of the mining industry had been found. Therefore, in this study, besides the oil and petroleum project risk researches, construction project risk researches have been used widely for a review.

\subsection{Operational sequence of mining projects}

To understand the roots of a project risk, one must consider the characters of the project process. Project characteristics differ due to the industry uniqueness. Major mining projects 
generally have six distinct phases; scoping studies, prefeasibility studies, definitive feasibility studies, design and construction, operations, and closure (Figure 2).

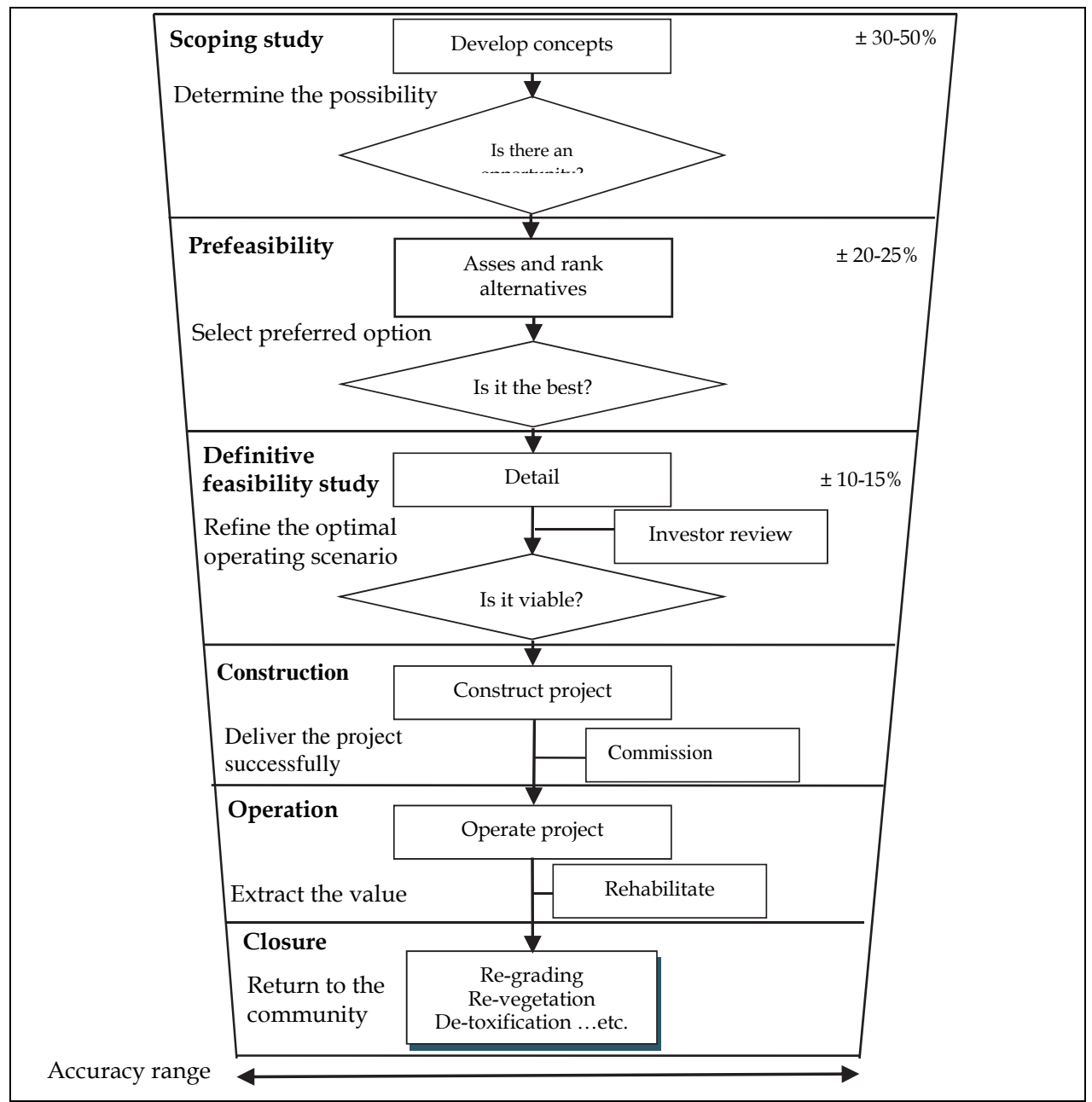

Fig. 2. The mining project development framework

The above Figure (2) was developed based on the original mining project development framework of Mackenzie \& Cusworth (2007). Each of these project phases serve an important purpose and requires a specific set of management skills. Furthermore, the framework recognizes that the feasibility study process is repetitive and indeed not all projects will progress through all the phases. At the end of each primary three phases, a decision is made whether to stop the project or progress to the next phase. It is usually difficult for the team to reach such a conclusion after spending considerable time, effort and resources on the study. Thus, the studies often do not progress smoothly through the study phases. The framework provides clear decision points after the completion of each phase, 
though in practice, a decision to reassess a project or abandon a study can be made at any time. As the project advances through, the accuracy of each phase improves. The typical accuracies of cost estimates for the study levels are illustrated on the top right corners of each box.

The framework in Figure 2 may be applied slightly different in each countries due to their legal policy and characteristics. To demonstrate the uniqueness, mining project process framework in Mongolia was developed and explained.

\subsubsection{Mining projects in Mongolia}

A process flow chart for mining projects was developed by interviewing experienced professionals working in the Mongolian mining industry (Figure 3).

A typical process generally consists of exploratory, planning, construction, operational, and a closure phase. These phases can have several stages as follows:

1. The exploratory phase. Under Mongolian law (Ашигт малтмалын тухай хууль, [Minerals Law] 2003), the national government maintains ownership of all mineral reserves. Private parties receive license for exploration and mining rights from the government. A contract agreement between the government and the mining company stipulates the terms of the license. Companies, after indicating a specific territory which is believed to have certain amount of a particular type of mineral deposit, start to negotiate the "exploration license" from the government agency if the land is available. Occasionally, companies that has an exploration license and no fund for exploration work, does consider selling the license or transforming certain percentage of it. Subsequently, the exploration phase begins with a team of several geology engineers, who usually work for months, during the summer, to identify the possible amount of resource under the territory along with its quality. Sometimes the mining companies hire other companies that specifically carry exploration work on a contract basis. The exploration work consists of three main fractions including detailed, definitive and mining. After the exploration work, the exploration team prepares a report that includes the assays, geological pictures, resource calculation and the type of technology and machines required for operating the mining work. If the company decides that the resource amount is sufficient, they will further perform a cost-benefit analysis. Clearly, if the management sees the possible benefits in implementing the project, they will proceed further with the project.

Environmental monitoring process starts as soon as the exploration work starts and it is continued until ownership of the territory is returned to the local community when the exploration work is finished or when the mine is closed.

2. The planning phase. Based on the set of exploration work, the company will submit it's exploration work report to the Minerals' Committee of Mongolia for assessment. Once the exploration report is approved, the company will provide set of documents such as the technical and economical feasibility study report, enivronmental monitoring work plan in order to register the mineral deposit data in the National Mineral Resource Book. The reason for this is to obtain the "mining license" from the government agency. Companies can also acquire a "mining license" from a seller who currently is in hold of the license or buy a share of the company that holds the "mining license". By analyzing the exploration reports, which demonstrate the information about the territory mineral resources, companies can make a decision to purchase the mining license. Furthermore, there are territories which was explored previously with the government fund. The "mining license's" for these territories can be obtained based on an exclusive contract with the government. 


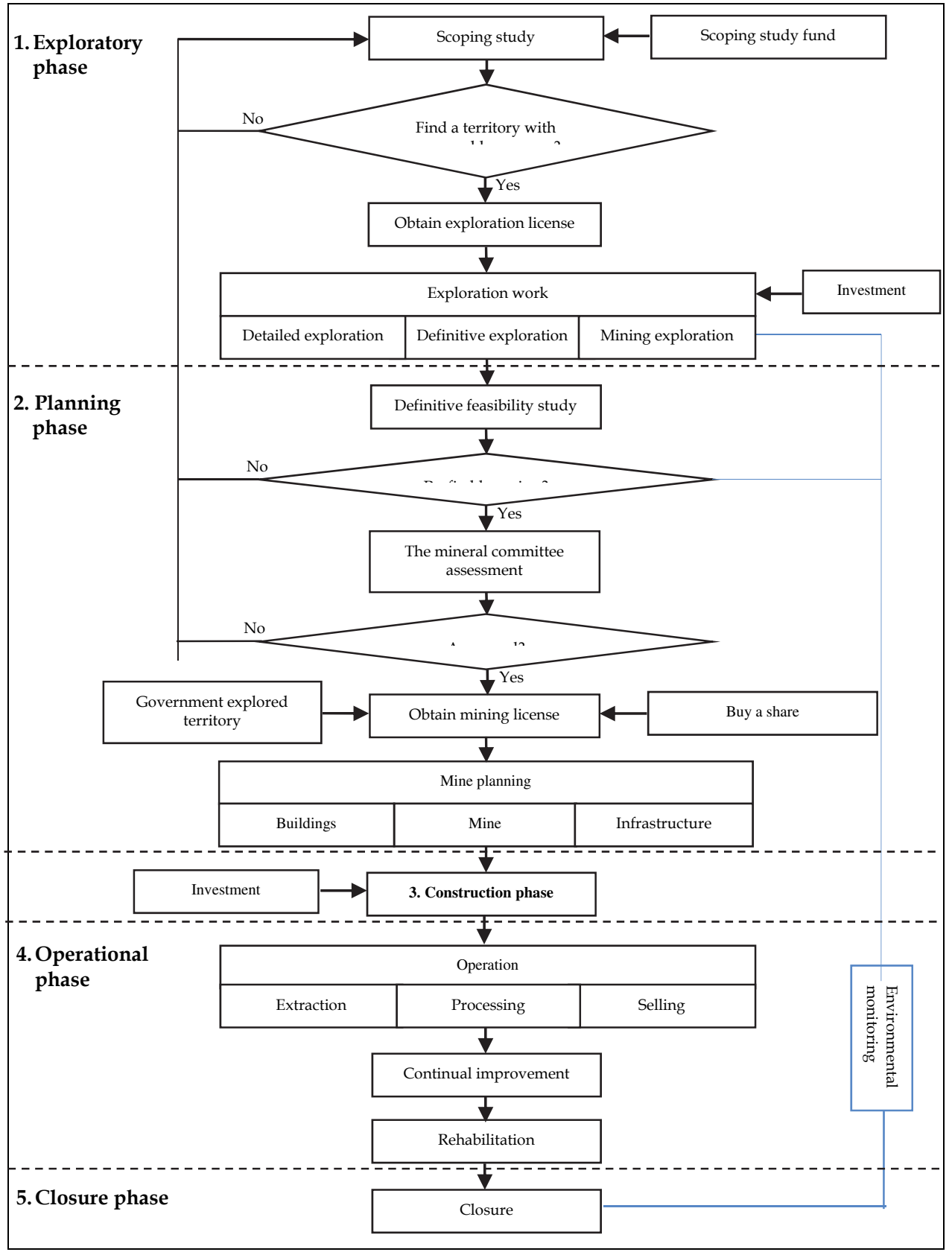

Fig. 3. Mining project process flow chart (Mongolian case) 
Once all the legal aspects are in place, the company will starts it's mine planning, including the buildings and infrastructure that is required to be built. These set of plans are often refered as the master plan of the mine.

3. The construction phase. The construction phase will start in accordance to the master plan of the mine. If necessary, companies can acquire investments from an outside resource such as financial institutions. Frequently, one of the sources for investment is to sell the project share or bond through broker companies at the stock exchange market. Large international investments in the mining field are regularly held in the Canadian, British and Australian stock exchange markets.

4. The operational phase. This phase will begin under the following condition:

- The main constructions for the mine, such as the enrichment factory (if necessary) assembly, accommodation facilities for the manpower, are completed;

- $\quad$ All machines and equipments had arrived on site;

- The necessary manpower is acquired and trained.

A typical mining operation involves extraction process where the mineral is extracted from the ground, processing of the mineral and selling. The selling process may include transportaion to the buyer's market.

During operational process a continious improvement is very important to lower bottlenecks, reduce cost and increase efficiency. Furthermore, in this phase, the rehabilitation process is intensified.

5. The closure phase. The permanent closure of a mine involves re-grading and revegetation, removal and disposal of stored fuels and chemicals, structure tear down, removal of roads and ditches, capping of tailings, waste detoxification, and reestablishment of drainage ways (United States Environmental Protection Agency, 1997). Many features of mines such as open pits, waste dumps, and impoundments of tailings are permanent and can degrade long after the mine has been closed, causing further environmental damage (Miranda et. al., 2003).

\subsection{Risk identification}

Risk identification is a process of determining which risks may affect the project and documenting their characteristics (PMI, 2008). Risk may be identified by understanding and reviewing the project plans, brainstorming with and interviewing experts, looking into previous risk related experiences and a database.

\subsubsection{Literature review}

Large construction projects and mining projects may share risks with similar characteristics because both are uncertain, complicated and costly. Therefore, number of researches on construction risks in several countries was conducted. However, no PRM study of Mongolia has been found up to date.

Construction project risk studies conducted in countries such as Hong Kong (Shen, 1997), Kuwait (Kartam \& Kartam, 2001), Vietnam (Luu et. al., 2009), China (Fang et. al., 2004; de Camprieu et. al., 2007), India (Ling \& Hoi, 2006), United Arab Emirates (UAE) (El-Sayegh, 2007), Palestine (Enshassi \& Mosa, 2008), Australia (Lyons \& Skitmore, 2004) and Taiwan (Wang et. al., 2003) was found and used to create a long-list of possible risks of the mining projects implemented in Mongolia. Some of the risks which were considered to share a similar effect on mining projects implemented in Mongolia were gathered in Table 1. 


\begin{tabular}{|c|c|c|c|c|c|c|c|c|c|}
\hline \multirow[t]{2}{*}{ Risk description } & \multicolumn{9}{|c|}{ Countries of the study } \\
\hline & Vietnam & Kuwait & China & Palestine & $\mathrm{UAE}$ & India & Australia & $\begin{array}{l}\text { Hong } \\
\text { Kong }\end{array}$ & Taiwan \\
\hline Owners' financial difficulties & 1 & 1 & 2 & 8 & 14 & & & & \\
\hline $\begin{array}{l}\text { Owners' unreasonably imposed tight } \\
\text { schedule }\end{array}$ & & & & & 2 & & & & \\
\hline Unmanaged cash flow & & & & 30 & & & & & \\
\hline Inadequate experience & 2 & & & 23 & & & & & \\
\hline $\begin{array}{l}\text { Lack of capable and responsible site } \\
\text { supervisors }\end{array}$ & 11 & & & & & $\mathrm{n} / \mathrm{a}$ & & & \\
\hline Subcontractors' poor management & & & 9 & & & & & & \\
\hline $\begin{array}{l}\text { Shortage in manpower supply and } \\
\text { availability }\end{array}$ & & 3 & & & 7 & & 2 & 3 & \\
\hline Shortage of skills/techniques & 14 & & & & & & 3 & 5 & \\
\hline Varied labor and equipment productivity & & & & 32 & & & & & \\
\hline Lack or departure of qualified staff & & & & & 9 & & & & \\
\hline Labor strikes and disputes & & & 45 & & 34 & & & & \\
\hline Low productivity of labor and equipment & 16 & 6 & 12 & & 20 & & & 6 & \\
\hline Human/organizational resistance & & 26 & 41 & & & & 6 & & \\
\hline Accidents during construction & & 23 & 20 & 3 & 33 & & & & \\
\hline $\begin{array}{l}\text { Breakdown of special machinery } \\
\text { equipment }\end{array}$ & & & 39 & & & & & & $\mathrm{n} / \mathrm{a}$ \\
\hline $\begin{array}{l}\text { Shortage in material supply and } \\
\text { availability }\end{array}$ & & & & 12 & 10 & & & 4 & \\
\hline Shortage in equipment availability & & & & 16 & 18 & $\mathrm{n} / \mathrm{a}$ & & & \\
\hline Late delivery of materials and equipments & & & 28 & & & & & & $\mathrm{n} / \mathrm{a}$ \\
\hline Lack of information & & & & & & & 4 & & \\
\hline Regulatory risks & & 19 & & & & $\mathrm{n} / \mathrm{a}$ & & & \\
\hline Changes in laws and regulations & & 22 & 25 & 28 & 35 & & & & $\mathrm{n} / \mathrm{a}$ \\
\hline Government's improper intervention & & & 11 & & & & & & \\
\hline Corruption and bribes & & & 23 & & 37 & & & & \\
\hline Delays in approvals & & & & & 8 & & & & \\
\hline Inclement weather & 12 & 21 & 26 & 33 & 40 & & & 2 & \\
\hline Environmental factors & & 24 & & 24 & & $\mathrm{n} / \mathrm{a}$ & & & $\mathrm{n} / \mathrm{a}$ \\
\hline
\end{tabular}

Table 1. List of construction project risks in various countries

The risk descriptions are listed in the left side column, and the risk rankings based on their impact on project failure according to the literatures was positioned next to each risk. Finally, the countries, which the risks are considered as significant during project implementation, are noted in the second row of the table.

The list of risks in Table 1 was used as a long-list for the risk identification process in the Mongolian mining industry. Countries in the table were chosen because they presumed to have certain similar characteristics with Mongolia. For example, Vietnam, China, Hong Kong, India and Taiwan are all among the developing economies in Asia and the selected risks were considered that it has a matching impact rate in projects implemented in 
Mongolia. Some of the characteristics such as political instability, corruption, lack of managers with the appropriate level of PM know-how of Mongolia are analogous with the above mentioned countries. However, the case of Australia was used to observe the risks in more developed counties. A number of risks were similar with the less developed countries which can be seen in Table 1.

\subsubsection{Brainstorming and interviewing}

Brainstorming and interviewing was performed with mining engineers and project managers with an experience working in Mongolia. Flow chart (Figure 3) is a very useful tool in risk identification, as each process can be talked through with cause and effect diagram. Based on the long-list and further discussions with experienced project managers and researchers the following list in Table 2, of MPRs in Mongolia were selected as the most common and significant to the project success. The risks were divided into two segments, risks that derive from an internal and an external environment.

\begin{tabular}{|r|l|l|}
\hline & List of risks (internal) & List of risks (external) \\
\hline 1 & Incorrect mineral resource calculation & Diesel shortage in the country \\
\hline 2 & Owner's financial difficulties & Railway transportation delay \\
\hline 3 & Incorrect financial resource calculation & Unpredicted environmental damages \\
\hline 4 & $\begin{array}{l}\text { Not enough fund for the environmental } \\
\text { recovery }\end{array}$ & Boycotting \\
\hline 5 & $\begin{array}{l}\text { Unsufficient employement safety } \\
\text { substances }\end{array}$ & $\begin{array}{l}\text { Government bureaucracy for obtaining } \\
\text { licenses }\end{array}$ \\
\hline 7 & $\begin{array}{l}\text { Shortage of skilled manpower for the } \\
\text { mining machinery }\end{array}$ & $\begin{array}{l}\text { Pressure from the government inspectors } \\
\text { effect case only) }\end{array}$ \\
\hline 8 & $\begin{array}{l}\text { Unsufficient skills of the project } \\
\text { managers }\end{array}$ & $\begin{array}{l}\text { Price fluctuation of minerals (negative effect } \\
\text { case only) }\end{array}$ \\
\hline 9 & $\begin{array}{l}\text { Accidents during construction and } \\
\text { operation }\end{array}$ & $\begin{array}{l}\text { Foreign exchange rate fluctuation (negative } \\
\text { effect case only) }\end{array}$ \\
\hline 10 & Poor management & Shortage of experts \\
\hline 11 & Irresponsibility of the workers & Shortage of local manpower \\
\hline 12 & Shortage of equipments & Poor infrastructure \\
\hline 13 & Poor internal communication & Demand fall of the mineral \\
\hline 14 & Shortage of machinery & Political instability \\
\hline 15 & Employee strike & Incrase of competition \\
\hline
\end{tabular}

Table 2. List of mining project risks in Mongolia

The identified risks (Table 2), were determined based on the mining industry characteristics, as well as the country's unique features. For example, in petroleum explorations, as economical and technological resources are limited, managers of these companies frequently face important decisions regarding the best allocation these scarce resources among exploratory ventures that are characterized by substantial financial risk and geological uncertainty (Roisenberg et. al., 2009). Uncertainty is intrinsically involved in all petroleum venture predictions, and particularly in chance of discovery. Resource calculation is where the mining resources are discovered during the exploration process and risk from an 
incorrect resource calculation has a significant impact to project failure. Thus, the risk was included in the long-list of risks created. Furhtermore, Mongolia has its own unique characteristics because of its geographical position. The country is land locked and located between Russia and China. Therefore, transportation of goods such as equipments and machinery is carried by railway or trucks. The railway transportation is overly utilized and delays occur frequently. Furthermore, a mass of diesel is consumed by mining companies for the machineries such as bulldozers, excavators and trucks for transportation. The country is heavily dependent on diesel import from Russia, and occasionally the supply of diesel stops due to indefinite reasons. Thus diesel shortage is considered as a great risk of various projects implemented in the country.

\subsection{Risk analysis}

To analyze the risk which were identified in the previous section, a questionnaire was developed, to obtain perceptions of other mining project experts in Mongolia. An indication of the relative importance of these risks in the local mining practice is given by examining observations and judgments of those in the field. Based on employment position and work experience, the study inferred that the respondents have adequate knowledge of the activities associated with mining and related risks, as shown on Table 4.

\begin{tabular}{|l|l|}
\hline 1 & \multicolumn{2}{l|}{$\begin{array}{l}\text { Number of years worked in the } \\
\text { industry }\end{array}$} \\
\hline $0-3$ years & $39 \%$ \\
\hline $4-6$ years & $26 \%$ \\
\hline $7-9$ years & $15 \%$ \\
\hline More than 10 years & $19 \%$ \\
\hline Not answered & $1 \%$ \\
\hline $2 \begin{array}{l}\text { Knowledge of risk } \\
\text { management }\end{array}$ & \\
\hline Excellent & $8 \%$ \\
\hline Good & $36 \%$ \\
\hline Moderate & $42 \%$ \\
\hline A little & $10 \%$ \\
\hline None & $3 \%$ \\
\hline Not answered & $1 \%$ \\
\hline
\end{tabular}

Table 3. Respondent's profile

The questionnaire's readability, lucidity and effectiveness was tested by a reveiw of the preliminary questionnaire of two practitioners working in the mining sector of Mongolia. Their comments were contemplated in the contents of the final questionnaire. The 
questionnaire forms were distributed by the senior students of the School fo Economic Studies, National University of Mongolia. The students asked each respondent orally and filled the form on behalf of them. In total 200 questionnaires were filled by the employees of 58 mining companies operating in Mongolia. Data analysis software SPSS 12 was used for assessing the questionnaire data. The software made available to check the reliability of results and the validity.

The practitioners were asked to assess the previously defined 30 risks based on their probability of occurence and impact on projects (Table 4). Risk probability assessment investigates the ilkelihood that each specific risk may occur. Risk impact assessment investigates the potential effect on a project objective such as time, cost or quality.

In the left hand column of Table 4 is the list of 30 risks identified previously are ranked based on their probability of occurence. The probability rates evaluated by the respondents are shown in the following column. Furthermore, in the right hand column, the 30 risks were listed according to their magnitude of impact on project success, from starting from the most signifacant risk. The impact rate of each risk is listed in the fourth column from the left. In the survey, respondents were asked to circle the factors using two scales with numbers from 0 to 10 . A value of 10 indicated the highest impact to project failure or probability of occurance, while 1 indicated the lowest. Respondents had to circle numbers from 0-10 which best indicated their opinion. The value 0 indicates that the practitioner believes that there is no impact of the risk to project failure.

The analysis showed that the respondents perceived "Incorrect mineral resource calculation" as the highest risk that contributed to project failure with the highes probability of occurence. Inaccurate geological reports, drilling and assay result and magnetic works of exploration bring high risk to mining projects. The exact geological layers and the metal dispersion system are extremely difficult to predict. Therefore, mineral resources can be estimated incorrectly or the average ore concentration can be inconclusive. However, the estimated resource is the main objective for implementing the project, which is the main income that will pay back the project investment and make profit. Thus, it is one of the most important aspects in mining project development to calculate the resource precisely as possible. Incorrect resource calculation reflects one of the largest contributions to a project failure.

Furthermore, risks from the changes in laws and regulation has a high ranking in probability of occurence due to the several changes in the Mineral law of Mongolia for the last number of years.

Moreover, it has been revealed that a majority of project owners do not effectively plan the financial segment of the project, which usually does not include any cost from the risk factors that may occur during the project implementation.

According to further interview, when managers, in Mongolia, calculate the project budget, typically include contingency amount which equals to 8 percent of the total project funds. The contingency fund is usually spent for an alternative features along the project implementation, and is nonexistent when the designated requisite arises. However, the interviewed participants supposed that the project owners do realize that the industry has exceptionally high risk, especially when the project implementation requires a lot of investment throughout all of its phases. Thus, the following high ranking risks such as "owner's financial difficulty" is apparent. 


\begin{tabular}{|c|c|c|c|c|}
\hline $\begin{array}{l}\text { Risks prioritizing based on the } \\
\text { probability of occurance }\end{array}$ & Probability & Ranking & Impact & $\begin{array}{l}\text { Risks prioritizing based on the } \\
\text { impact on project success }\end{array}$ \\
\hline Incorrect mineral resource calculation & 6.15 & 1 & 7.86 & Incorrect mineral resource calculation \\
\hline $\begin{array}{l}\text { Changes in laws and regulations } \\
\text { (negative effect case only) }\end{array}$ & 5.76 & 2 & 6.69 & $\begin{array}{l}\text { Incorrect financial resource } \\
\text { calculation }\end{array}$ \\
\hline $\begin{array}{l}\text { Price fluctuation of minerals (negative } \\
\text { effect case only) }\end{array}$ & 5.63 & 3 & 6.45 & Owner's financial difficulties \\
\hline Owner's financial difficulties & 5.51 & 4 & 6.27 & Diesel shortage in the country \\
\hline Political instability & 5.49 & 5 & 6.16 & $\begin{array}{l}\text { Price fluctuation of minerals (negative } \\
\text { effect case only) }\end{array}$ \\
\hline Technical problem (breakdown) & 5.47 & 6 & 6.13 & $\begin{array}{l}\text { Changes in laws and regulations } \\
\text { (negative effect case only) }\end{array}$ \\
\hline Poor infrastructure & 5.44 & 7 & 5.95 & Poor management \\
\hline $\begin{array}{l}\text { Shortage of skilled manpower for the } \\
\text { mining machinery }\end{array}$ & 5.40 & 8 & 5.90 & Technical problem (breakdown) \\
\hline $\begin{array}{l}\text { Foreign exchange rate fluctuation } \\
\text { (negative effect case only) }\end{array}$ & 5.31 & 9 & 5.87 & Railway transportation delay \\
\hline Shortage of local manpower & 5.28 & 10 & 5.86 & $\begin{array}{l}\text { Shortage of skilled manpower for the } \\
\text { mining machinery }\end{array}$ \\
\hline Incorrect financial resource calculation & 5.25 & 11 & 5.76 & Demand fall of the mineral \\
\hline $\begin{array}{l}\text { Government bureaucracy for obtaining } \\
\text { licenses }\end{array}$ & 5.18 & 12 & 5.75 & $\begin{array}{l}\text { Unsufficient skills of the project } \\
\text { managers }\end{array}$ \\
\hline \begin{tabular}{|l|l} 
Shortage of equipments \\
\end{tabular} & 5.16 & 13 & 5.70 & Shortage of equipments \\
\hline $\begin{array}{l}\text { Unsufficient skills of the project } \\
\text { managers }\end{array}$ & 5.16 & 14 & 5.54 & Irresponsibility of the workers \\
\hline $\begin{array}{l}\text { Pressure from the government } \\
\text { inspectors }\end{array}$ & 5.03 & 15 & 5.53 & Shortage of machinery \\
\hline Irresponsibility of the workers & 4.90 & 16 & 5.43 & $\begin{array}{l}\text { Foreign exchange rate fluctuation } \\
\text { (negative effect case only) }\end{array}$ \\
\hline $\begin{array}{l}\text { Not enough fund for the environmental } \\
\text { recovery }\end{array}$ & 4.88 & 17 & 5.32 & $\begin{array}{l}\text { Accidents during construction and } \\
\text { operation }\end{array}$ \\
\hline Shortage of machinery & 4.74 & 18 & 5.23 & $\begin{array}{l}\text { Government bureaucracy for } \\
\text { obtaining licenses }\end{array}$ \\
\hline Poor management & 4.71 & 19 & 5.12 & Boycotting \\
\hline Demand fall of the mineral & 4.70 & 20 & 5.11 & Unpredicted environmental damages \\
\hline Poor internal communication & 4.64 & 21 & 5.06 & Poor infrastructure \\
\hline Railway transportation delay & 4.59 & 22 & 5 & $\begin{array}{l}\text { Not enough fund for the } \\
\text { environmental recovery }\end{array}$ \\
\hline $\begin{array}{l}\text { Unsufficient employement safety } \\
\text { substances }\end{array}$ & 4.46 & 23 & 4.95 & Political instability \\
\hline Boycotting & 4.41 & 24 & 4.79 & $\begin{array}{l}\text { Unsufficient employement safety } \\
\text { substances }\end{array}$ \\
\hline $\begin{array}{l}\text { Accidents during construction and } \\
\text { operation }\end{array}$ & 4.39 & 25 & 4.77 & $\begin{array}{l}\text { Pressure from the government } \\
\text { inspectors }\end{array}$ \\
\hline Incrase of competition & 4.38 & 26 & 4.71 & Employee strike \\
\hline Unpredicted environmental damages & 4.28 & 27 & 4.68 & Poor internal communication \\
\hline Diesel shortage in the country & 4.18 & 28 & 4.37 & Incrase of competition \\
\hline Shortage of experts & 4.02 & 29 & 4.13 & Shortage of experts \\
\hline Employee strike & 3.40 & 30 & 3.91 & Shortage of local manpower \\
\hline
\end{tabular}

Table 4 . Risk probability and impact assessment 


\subsection{Risk evaluation}

To properly evaluate project risks, one must consider both the probability of risk occurrence and the impact on project objectives once the risk event occurs. This is achieved best by plotting the risk probability - impact matrix (El-Sayegh, 2007). The identified thirty risks were positioned on the probability and impact matrix, as shown in Figure 4 . In the matrix, the $x$-axis represents the probability value while the $y$-axis represents the impact value. Both scales are $1-10$ (one being very low to 10 being very high). For a clearer view of the figure, only scales from 3 to 7 for the $x$-axis and 3 to 8 for the $y$-axis were shown in Figure 4 . The probability and the impact values were calculated based on the average scale provided by the respondents.

It was assumed, in this study, that if the average probability and impact of the risk is more than five, then the risk is considered as significant wich is in need of high attention. The matrix shows that risks within the circle of priority number 1 are the ones with highest probability and impact. Risks in the circle of priority number 2 are the ones with high probability but medium impact on project failure. Conversely risks in the circle of priority number 3 are the ones with medium probability and high impact to project failure. Finally, risks in the circle of priority number 3 are the ones with medium probability and medium impact.

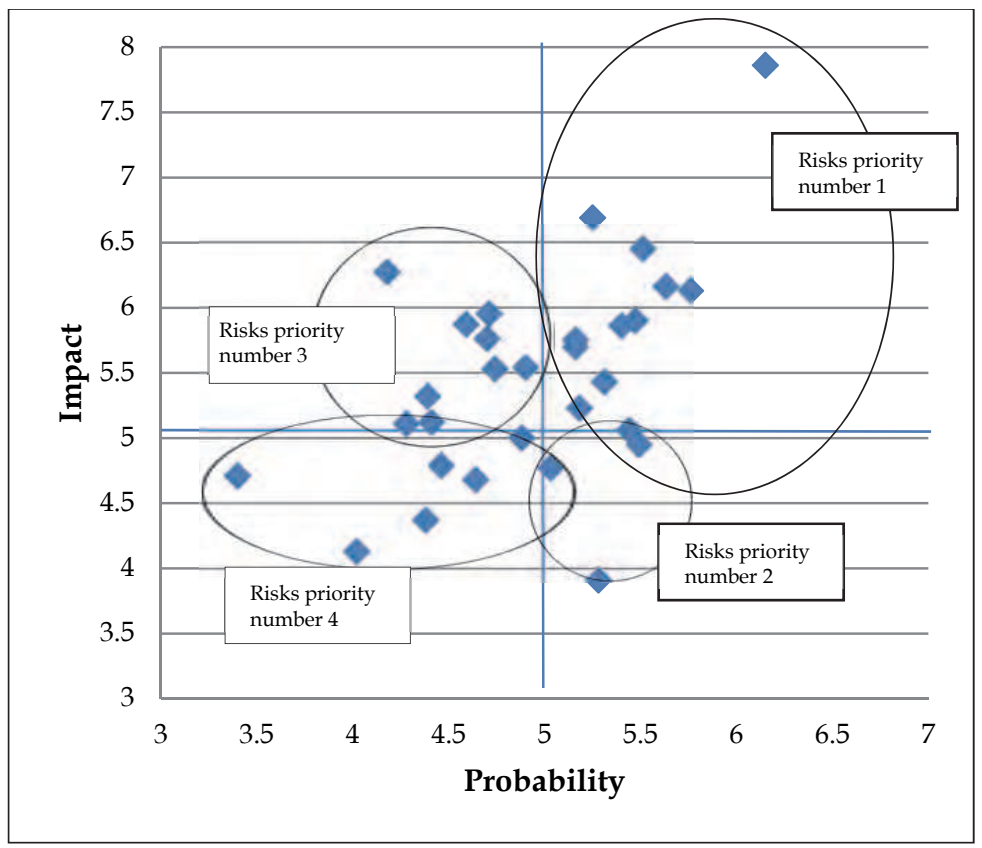

Fig. 4. Probability and impact matrix

\subsection{Risk mitigation}

Risk mitigation actions are adopted by practitioners to respond to various risks that threats the project objectives. This process follows the risk evaluation process so that the risk mitigation is concentrated on the most significant risks in the higher priority. 
The final part of the survey in this study was designed to identify if the practitioners in the Mongolian mining sector perform risk mitigation plan. The results from the survey were shown in Figure 5.

According to Figure 5, the majority of respondents answered that they do perform risk mitigation plan. Therefore, it can be assumed that most companies in Mongolia make an effort to perform their risk mitigation plans.

Finally, the usage of risk management tools by practitioners in the mining industry of Mongolia were evaluated (Figure 6). The two tools used mainly by the practitioners

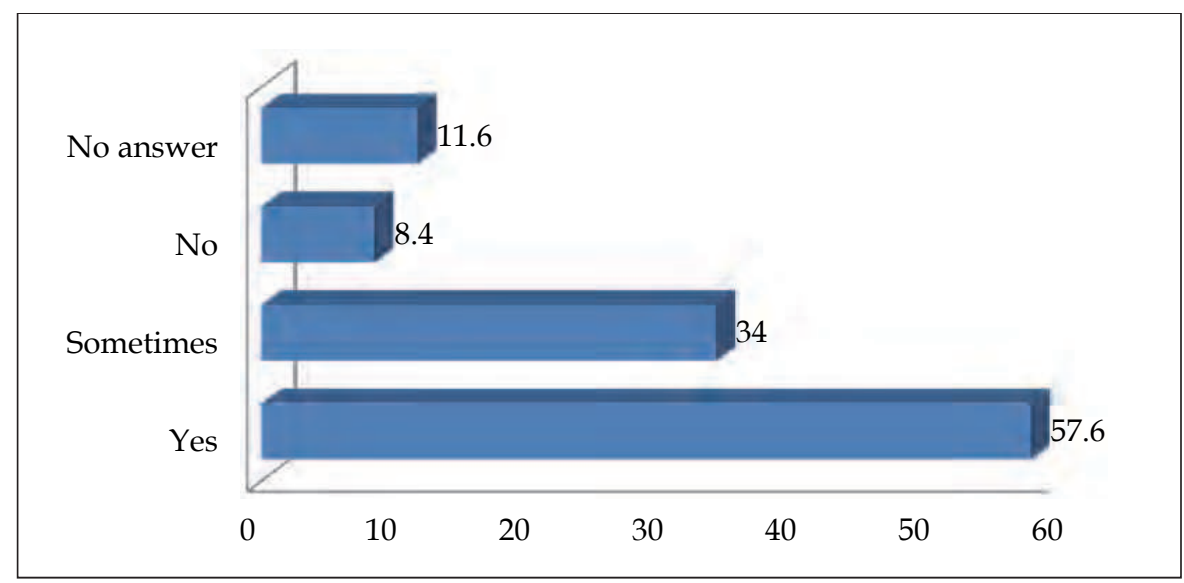

Fig. 5. The performance level of a risk mitigation plan

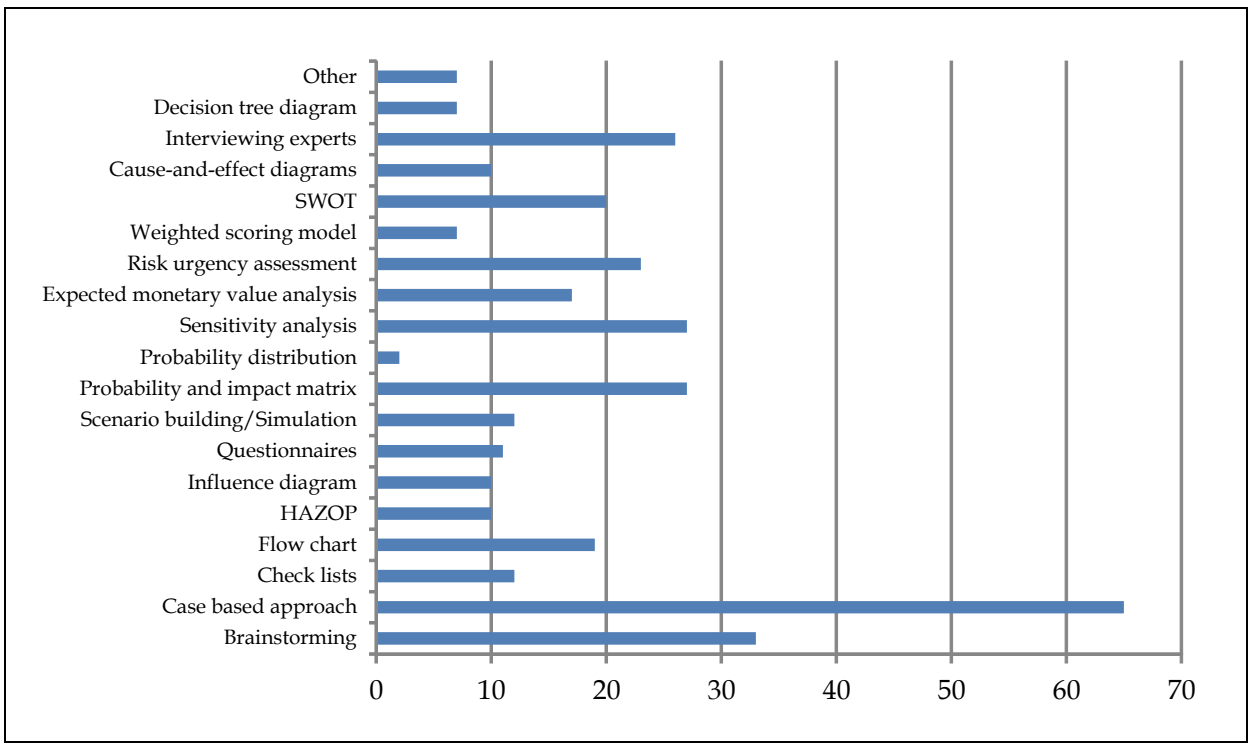

Fig. 6. Usage of risk management tools 
included case based apporach and brainstorming. Consistent with the results of Lyons and Skitmores' survey of PRM in the Queensland engineering construction industry (2004), brainstorming was the most common technique used in risk identification. No single risk assessment technique is best for all cases which is possibly the reason why the respondents have opted for the simplest approach. Tools such as probability distribution and simulation analysis were used seldom. The interview also suggested that, practitioners prefer to use simple methods that do not take much time or effort. The quantitative risk analysis tools are not considered to be an effective method due to various reasons such as insufficient knowledge and experience in these analysis tools and techniques and the difficulty of finding the true probability distribution for risks in practice. Shen (1997), in addition, suggested that according to his survey of PRM in Hong Kong, quantitative analytical techniques have been rarely used due to limited understanding and experience.

From this study, it is clear that the practitioners used the tools which were known to them and the tools they considered as the most effective.

One survey respondant mentioned that a "bank performance letter" can be used as an effective tool for reducing risk in mining project investment as it shows the company credit reputation. For investment companies this document ensures their confidence in the mining company. Furthermore, as mentioned earlier, financial problems are one of the major risks of mining companies, which is a reason why the bank performance letter can be useful tool for obtaining reliable information.

\subsection{Risk learning}

One of the fundamental and major steps in PRM is to identify and assess the potential risks in the project. Every project contains some degree of risk; and yet, most project managers are ill prepared when it comes to identifying or adequately addressing potential risks (Wang et. al., 2004). Managers struggle to identify all the risks of projects because it is time-consuming and counterproductive. Attempts to consider every risk are doomed to failure (El-Sayegh, 2007). The trick is to identify the most critical risks and control them (Barkley, 2004). Thus, it is important to determine the most significant risks in the mining industry of the country where the project is planned to be implemented.

The identification of risk and the creation of a risk list are dependent upon many factors, such as past experience, personal tendency, and the possession of information. Therefore, almost no two risk analysts will make the same judgment when they identify risks from the same project (Ren, 1994).

For managers, an information database with exclusive information of the local risk characteristics of mining projects can be argued to be effective support for mining project managers.

\subsubsection{Project risk information database}

Generally, each project team performs risk management activities and retains what it learns within the project. Thus many of the things learned from various projects need to be reinvented in new projects (Varadharajulu \& Rommel, 2008). However, finding information of previous local projects with similar characteristics is time, effort and money consuming and could be avoided if there is a process and mechanism by which project learning is shared among other project managers. Consequently, an information database solution for risk management process for information sharing among project managers is required. 


\subsubsection{Creating the project risk information database}

Perhaps, previous literature, case studies and survey analysis are essential information for creating risk database. Commonly, large projects implementation takes time and gathering project learning and risk information from them will also take time. Therefore, in addition to the recently implemented project learning, previous studies will contribute as a lot of information of risk and the ways risk was managed (Figure 7). Companies which share similar project characteristics can create a joint risk database and distribute risk information for one another.

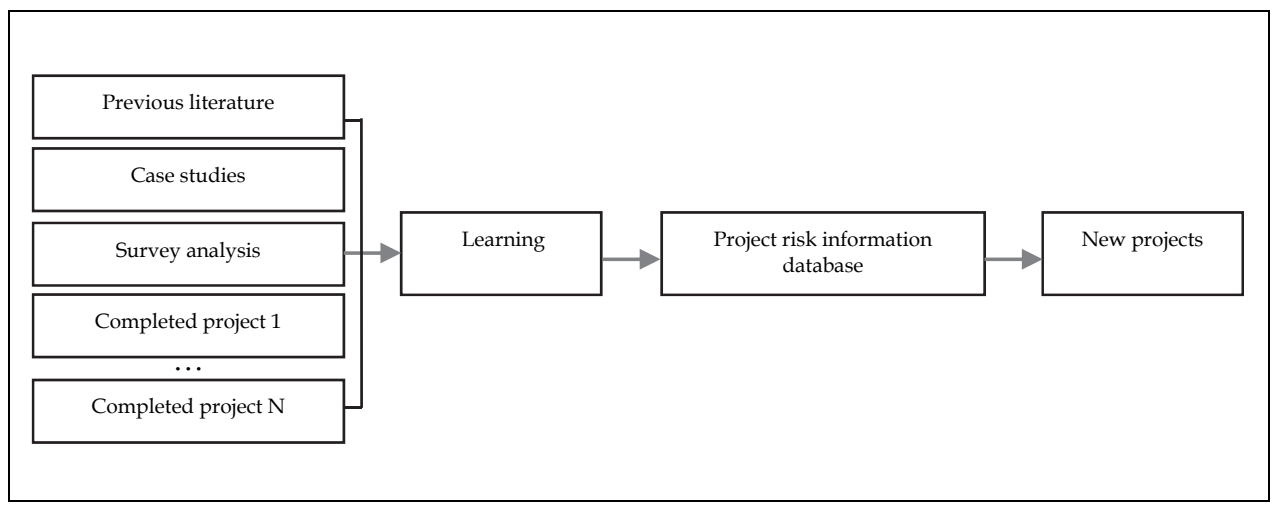

Fig. 7. Project risk information database

While providing inputs, a panel of specialists of the companies should review the submitted risk information and the appropriateness. Only the generic and practical information for future projects should be inserted.

\subsubsection{Using the project risk information database}

As the new project starts, project leader will go through the risk database. In order to save time assuming the information in the database is a great deal of amount the input needs to be categorized. The information in the database is categorized by the type of the projects such as construction or mining project. Then the information is further categorized into place of project implementation to find out the local risks with unique characteristics. Subsequently, the list of literature and project learning of the required project type and location which the project was implemented will be revealed (Figure 8). The risk database needs to have a good guideline on the risk description and how it was managed. The database is required to be maintained by a team appointed by the companies or the database creator. Additionally, the information can be utilized to perform various studies such as simulation analysis on the risk probability of occurrence and impact to project failure in the alleged countries in the supposed types of projects.

The database will help project managers to save effort, time and money and also find out the possible risks and understand them at an early stage. Furthermore, gathered information can be exploited for various project risk management researches which may be helpful for generating productive ideas and techniques that can be utilized in the modern project management. 


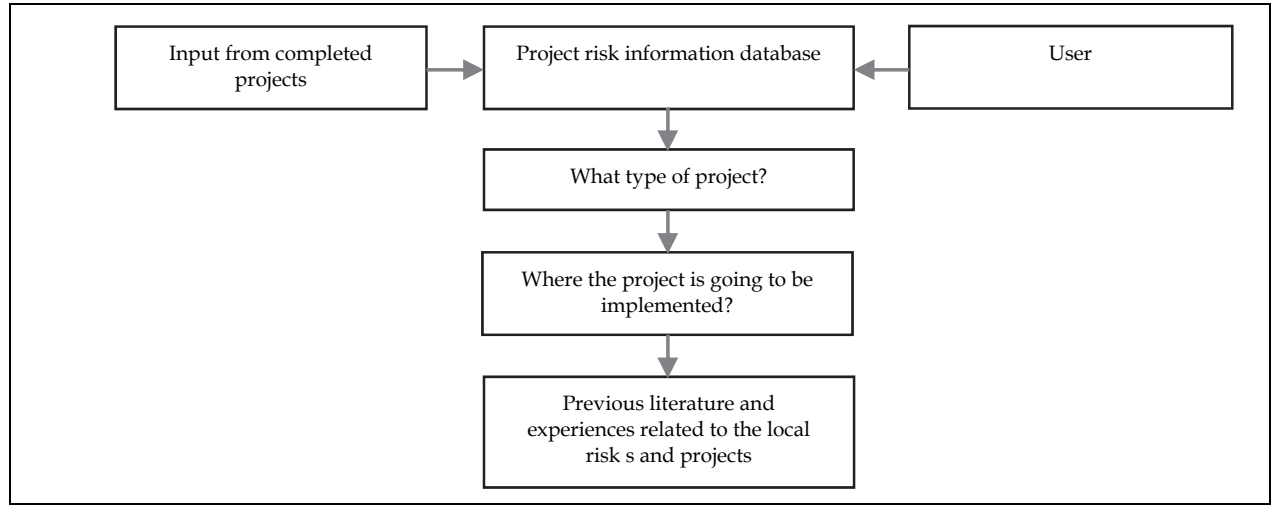

Fig. 8. Project Risk Information Database: Categorizing the Risks

\section{Conclusion}

The chapter describes risk management processes based on a study of the current views and practices of mining projects in Mongolia. Project risks and their relative contribution to project failure was studied. Moreover risk management tools used by those in the field were identified. The identified 30 risks which have highest contribution to mining project failure in Mongolia may be useful for project managers in their future project implementations and risk management processes.

The study shows a necessity for a risk management culture in organizations in the country. Additionally, a risk management method which is suitable for the Mongolian mining industry which is stipulated by a research and an analytic study is required. It may be simply impossible to predict the future of projects over a 10-15 year period of work. However, a framework for a risk management approach that is apt for the characteristics of the country and culture of the people can be suggested for future research.

Furthermore, creation of a risk management database will help project managers to save effort, time and money and also find out the possible risks and understand them at an early stage. The gathered information can be exploited for various project risk management researches which may be helpful for generating productive ideas and techniques that can be utilized in the modern project management.

Finally, some of the risks described in this study may also share same impact to other types of projects implemented in Mongolia, therefore, studies in this matter is also suggested for future researches.

\section{References}

Barkley, B. T. (2004). Project Risk Management, McGraw-Hill, New York, USA

Castle, G. R. (1985). Feasibility studies and other pre-project estimates: How reliable are they?, Proceedings of the Finance for the Minerals Industry, ISBN 0895204355, New York, February, 1985 
Chapman, C. (1997). Project risk analysis and management - PRAM the generic process, International Journal of Project Management, Vol. 15, No. 5, (October 1997), pp. 273281

Charette, R. (2002). The state of risk management 2002: Hype or reality, Industry Report, Cutter Consortium, Arlington, MA

Cooper, D.; Grey, S.; Raymond, G. \& Walker, P. (2005). Project Risk Management Guidelines: Managing Risk in Large Projects and Complex Procurements, John Wiley \& Sons Ltd., England

De Camprieu, R.; Desbiens, J. \& Feixue, Y. (2007). 'Cultural' differences in project risk perception: An empirical comparison of China and Canada. International Journal of Project Management, Vol. 25, pp. 683-693

Del Cano, A. \& de la Cruz, M. P. (2002). Integrated methodology for project risk management, Journal of Construction Engineering and Management, Vol. 128, No. 6, pp.473-485

Edwards, P. J. \& Bowen, P. A. (2005). Risk management in project organizations, Elsevier, Butterworth Heinemann

El-Sayegh, S. M. (2007). Risk assessment and allocation in the UAE construction industry. International Journal of Project Management, Vol. 26, pp. 431-438

Enshassi, A. \& Mosa, J. A. (2008). Risk management in building projects: owners' perspective. The Islamic University Journal (Series of Natural Studies and Engineering), Vol. 14, No.1, pp. 95-123

Fang, D.; Li, M.; Fong, P. S. \& Shen, L. (2004). Risks in Chinese construction market contractors' perspective. Journal of Construction Engineering and Management, Vol. 130, No.6, pp. 853-861

Floricel, S. \& Miller, R. (2001). Strategizing for anticipated risks and turbulence in large-scale engineering projects, International Journal of Project Management, Vol. 19, pp. 445-455

Fraser, D. C. (1984). An approach to major projects, Major Project Association, Oxford: Templeton College Press

Gardiner, P. D. (2005). Project Management: A Strategic Planning Approach, Palgrave Macmillan, New York

Gypton, C. (2002). How have we done? Feasibility study performance since 1980, Engineering and Mining Journal, Vol. 302, No. 1, pp. 41-46

Jacinto, C. M. C. (2002). Discrete event simulation for the risk of development of an oil field, Proceedings of the 2002 Winter Simulation Conference, ed. E. Yucesan, C. H. Chen, J. L. Showdon, and J. M. Charnes, pp. 1588-1592

Kartam, N. A. \& Kartam, S. A. (2001). Risk and its management in the Kuwaiti construction industry; a contractors' perspective. International Journal of Project Management, Vol. 19, pp. 325-335

Ling, F. Y. Y. \& Hoi, L. (2006). Risks faced by Singapore firms when undertaking construction projects in India. International Journal of Project Management, Vol. 24, pp. 261-270

Luu, V. T.; Kim, S.; Tuan, N. V. \& Ogunlana, S. O. (2009). Quantifying schedule risk in construction projects using Bayesian belief networks. International Journal of Project Management, Vol. 27, pp. 39-50 
Lyons, T. \& Skitmore, M. (2004). Project risk management in the Queensland engineering construction industry: a survey. International Journal of Project Management, Vol. 22, No.1, pp. 51-61

Mackenzie, W. \& Cusworth, N. (2007). The use and abuse of feasibility studies, Proceedings of the Project Evaluation Conference, pp. 1-12, Melbourne

Miller, R. \& Lessard, D. (2001). Understanding and managing risks in large engineering projects, International Journal of Project Management, Vol. 19, No. 8, pp. 437-443

Miranda, M.; Burris, P.; Bincang, J. F.; Shaerman, P.; Briones, J. O.; La Vina, A. \& Menard, S. (2003). Mining critical ecosystems: Mapping the risks, World Resource Institute, Washington DC

Noort, D. J. \& Adams, C. (2006). Effective mining project management systems, Proceedings of the International Mine Management Conference 2006, pp. 87-96

Perry, J. C. (1986). Risk management-an approach for project managers, International Journal of Project Management, Vol. 4, No. 4, pp. 211-216

Project Management Institute, Inc., (2008) A Guide to the Project Management Body of Knowledge: PMBOK guide - Fourth edition, Project Management Institute, Inc., ISBN 978-1-933890-51-7, Pennsylvania

Ren, H. (1994). Risk lifecycle and risk relationships on construction projects. International Journal of Project Management, Vol. 12, No.2, pp. 68-74

Roisenberg, M.; Schoeninger, C. \& da Silva, R. R. (2009). A hybrid fuzzy-probabilistic system for risk analysis in petroleum exploration prospects, Expert Systems with Applications, Vol. 36, pp. 6282-6294

Shen, L. Y. (1997). Project risk management in Hong Kong. International Journal of Project Management, Vol. 15, No.2, pp. 101-105

United States Environmental Protection Agency (1997). Office of air and radiation, Final report - Performance of selective catalytic reduction on coal-fired steam generating units

Varadharajulu, M. \& Rommel, C. (2008). Achieving yokoten in the process of risk management, BPM Enterprise.com. Retrived from http://www.bpmenterprise.com/content/c080623a.asp?action=print

Wang, M.; ASCE, M. \& Chou, H. (2003). Risk allocation and risk handling of highway projects in Taiwan. Journal of Management in Engineering, Vol. 19, No.2, pp. 60-68

Wang, S.Q.; Dulaimi, M.F. \& Aguria, M.Y. (2004). Risk management framework for construction projects in developing countries, Consturction Management Economics, Vol. 33, No.3, pp. 237-252

Ward, S. C. \& Chapman, C. (1991). Extending the use of risk analysis in project management, International Journal of Project Management, Vol. 9, No. 2, pp. 117-123

Williams, T. (1995). A Classified Bibliography of Recent Research Relating to Project Risk Management, European Journal of Operational Research, Vol. 85, pp. 18-38

Wyk, R.; van Bowen, P. \& Akintoye, A. (2008). Project risk management practice: The case of a South African utility company, International Journal of Project Management, Vol. 26, pp. 149-163

Ашигт малтмалын тухай хууль, [Minerals Law] (2003). Art. 11, Par. 11.1.6-8, (Mon). 


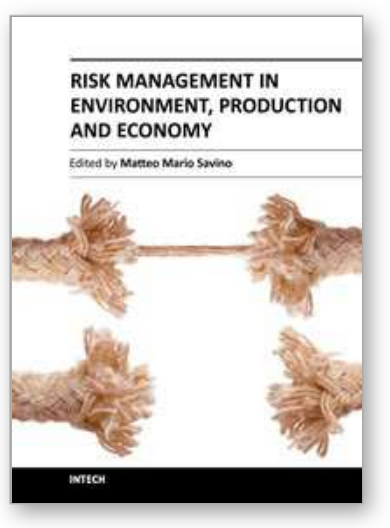

\author{
Risk Management in Environment, Production and Economy \\ Edited by Dr. Matteo Savino
}

ISBN 978-953-307-313-2

Hard cover, 214 pages

Publisher InTech

Published online 12, September, 2011

Published in print edition September, 2011

The term "risk" is very often associated with negative meanings. However, in most cases, many opportunities can present themselves to deal with the events and to develop new solutions which can convert a possible danger to an unforeseen, positive event. This book is a structured collection of papers dealing with the subject and stressing the importance of a relevant issue such as risk management. The aim is to present the problem in various fields of application of risk management theories, highlighting the approaches which can be found in literature.

\title{
How to reference
}

In order to correctly reference this scholarly work, feel free to copy and paste the following:

Undram Chinbat (2011). Risk Analysis in the Mining Industry, Risk Management in Environment, Production and Economy, Dr. Matteo Savino (Ed.), ISBN: 978-953-307-313-2, InTech, Available from:

http://www.intechopen.com/books/risk-management-in-environment-production-and-economy/risk-analysis-inthe-mining-industry

\section{INTECH}

open science | open minds

\section{InTech Europe}

University Campus STeP Ri

Slavka Krautzeka 83/A

51000 Rijeka, Croatia

Phone: +385 (51) 770447

Fax: +385 (51) 686166

www.intechopen.com

\section{InTech China}

Unit 405, Office Block, Hotel Equatorial Shanghai

No.65, Yan An Road (West), Shanghai, 200040, China

中国上海市延安西路65号上海国际贵都大饭店办公楼 405 单元

Phone: +86-21-62489820

Fax: +86-21-62489821 
(C) 2011 The Author(s). Licensee IntechOpen. This chapter is distributed under the terms of the Creative Commons Attribution-NonCommercialShareAlike-3.0 License, which permits use, distribution and reproduction for non-commercial purposes, provided the original is properly cited and derivative works building on this content are distributed under the same license. 